\title{
RESEARCHPAPER
}

\section{Effect of newer insecticides to natural enemies in the coastal rice ecosystem of Karaikal district, Union Territory of Puducherry}

\author{
K.S. KARTHICK, M. KANDIBANE AND K. KUMAR \\ Department of Agricultural Entomology and Nematology, Pandit Jawaharlal Nehru College of Agriculture and Research \\ Institute, KARAIKAL (PUDUCHERRY) INDIA \\ Email : kthick555@gmail.com
}

Article Info :Received : 05.11.2014; Revised : 12.02.2015; Accepted : 27.02 .2015

To study the effect of newer insecticides viz., flubendiamide $39.35 \mathrm{M} / \mathrm{M} \mathrm{SC}$, chlorantraniliprole $18.5 \mathrm{SC}$, thiamethoxam $25 \mathrm{WG}$, bifenthrin $10 \mathrm{EC}$, cartap hydrochloride $50 \mathrm{SP}$, indoxacarb $14.5 \mathrm{SC}$, emamectin benzoate $5 \mathrm{SG}$ and phosphamidon 40 SL to natural enemies of rice pests, a field experiment was conducted at the Eastern farm of Pandit Jawaharlal Nehru College of Agriculture and Research Institute (PAJANCOA and RI), Karaikal during late Rabi 2013 (Nov.- Feb.). Two foliar applications were carried out at an interval of fifteen days after leaf folder larvae reached economic threshold level $(10 \%)$. The results showed that the overall mean population of coccinellids was found to be more in the untreated check (1.31 and 1.65 / hill) followed by indoxacarb $14.5 \mathrm{SC}$ at 72.50 g a.i. / ha (0.92 and 1.16 / hill) in the first and second foliar application. The overall mean population of spiders was high in the untreated check (1.32 and 1.55 / hill), followed by indoxacarb $14.5 \mathrm{SC}$ at $72.50 \mathrm{~g}$ a. i. / ha (1.07 and 1.15 / hill) over the other treatments.

Key words : Newer insecticides, Predatory coccinellids, Spiders, Costal rice ecosystem

How to cite this paper : Karthick, K.S., Kandibane, M. and Kumar, K. (2015). Effect of newer insecticides to natural enemies in the coastal rice ecosystem of Karaikal district, Union Territory of Puducherry. Asian J. Bio. Sci., 10 (1) : 39-42. 